\title{
The Influence of Problem Based Learning Model and Cognitive Style on The Result of Learning Intermediate Financial Accounting 2
}

\author{
Nunuk Suryanti \\ Universitas Islam Riau \\ nunuksuryanti@edu.uir.ac.id
}

\begin{abstract}
This research was quasi experiment research which was aimed to find out the influence of Problem Based Learning Model and cognitive style on the result of learning Intermediate financial accounting 2 . The population was taken from students of accountancy education FKIP UIR who started attending college in education year 2014/2015 which was consisted of 4 classes. The sample was taken by using purposive sampling technique. The experiment class (Class 4C) was taught by using PBL model and control class (Class 4D) was taught by using Drill method in small group. The data was collected by using documentation, observation, and tests (pre test and post test). In addition, cognitive style was tested by using GEFT (Group Embedded Figure Test) which was developed by Witkin. The data was analysed by using independent sample $t$ test and dummy variable regression. The result of the research showed that neither PBL model nor cognitive style had significant influence on the result of learning intermediate financial accounting
\end{abstract}

Keywords-PBL, cognitive style, intermediate financial accounting 2 .

\section{INTRODUCTION}

Albrecht and Sack (Umar, 2014) observed that there was a decrease in student's achievement in accounting [1]. The same as the results of research conducted by Drennan and Rhode, 2010, Where there has been no memorable results for accounting at higher levels of education [2].

Accounting Education Change Commission suggested innovations in curriculum of accountancy for college in order that the graduate can synchronize their competence and qualification in work. The ability to think critically became important demand because students who have the ability to think critically can solve socio-scientific problem or practical problems [3]. Therefore, students who had been trained to think critical are more able to solve problems effectively [3].

International Financial Reporting Standards (IFRS) focused on concepts to conclude and opinions rather than technical things such as concept memorizing and counting practice. The graduates will face the big gap demand between the theories they get from school or college and practice at work. This phenomenon can be seen from conventional learning system of accountancy in common high school or vocational school and college which tends to focus on counting practice in making journal and making financial report rather than analysis. Therefore, students have less critical thinking capability, problem solving analysis, and communication capability. The one thing that should be the main focus is to train students to think, analyse, and interact [4].

Conventional accountancy education often produces graduates who master the knowledge about accountant profession only but they lack skills of analysing, communicating, giving opinion, problem solving, and other essential skills [5]. The American Accounting Association (AAA) in 1986 recommended that accountancy education should make accountancy learner active and independent rather than just information receiver. The Accounting Education Change Commission (AECC) recommended that students should prepare lifelong learning. The AECC also emphasized the importance of "learning by doing" and "group learning" [5].

The tight competition at work demands that students master the skill of critical thinking in solving any problem. Therefore, educators (especially accountancy educators) are expected to have knowledge and skill in designing and applying learning strategy which can develop the skill of critical thinking.

Educators are expected to be able to train students in order that they have critical thinking skill and other provisions which can be used in facing life challenge in the future. Therefore, it is important to design learning program which covers material from education curriculum and skill of critical thinking with the implementation of problem solving method. Nowadays, it can be seen that there is effort 
from educators to engage students in critical thinking activity [6] and students seldom use critical thinking skill to solve complex problem [7].

One of factors that influences students' skill of critical thinking in problem solving is cognitive style dimension. This dimension will influence the process of case analysis of tasks and questions in accountancy lecture subject especially Intermediate Financial Accountancy. This lecture subject is high level accountancy lecture subject which is quite hard for students. There are many students who failed in this subject since students must have higher critical thinking level and sufficient understanding of basic materials of accountancy [4].

Based on the fact explained above, it is need to increase the result of learning Intermediate financial accounting 2 (Akuntansi Keuangan Menengah 2/AKM) in order that students will not face difficulty in the next subjects and can pass with satisfying GPA even cumlaude. We need to analyse the characteristic of Financial Accountancy subject in order that we can take proper action.

Based on the result of final exam of AKM 2 in Fakultas Keguruan Ilmu Pendidikan (FKIP) in Universitas Islam Riau (UIR) in even semester of education year 2014 2015 , the mean score of 4 classes was 55 . When this number score was converted to alphabet score, we got " $D$ ". This fact gave image that the solution to increase the result of learning AKM 2 is needed given the importance of this subject.

Some characteristics of Financial Accountancy subject are: (1) need students who have skill of problem solving and can develop this skill [8], (2) the material contents need higher cognitive level, and (3) need higher skill in processing the previous knowledge [9]. Given the characteristic mentioned before, it is necessary to develop problem solving skill by developing students' tendency of cognitive style [10] and therefore we can take proper action in the next learning.

PBL is a model based on learning situations that teachers should design the learning curriculum based on students' perspectives and based on what is known, used, and organize various sources in their everyday life through guided participation. Eventually, students can develop the ability to solve their complex problems that they face in everyday life (16). Meanwhile, Duch (2001) argues that core and learning objectives are linked to problems and eventually can challenge students to develop higher levels of thinking such as analysis, synthesis, and evaluation (6).

Cognitive style in accountancy education research got most attention concerning student performance scoring [11] and therefore by knowing the dimension of cognitive style of student, cognitive style can be related to the result of learning Intermediate financial accounting 2[12]. Therefore, it is necessary to take proper action in selecting learning method and strategy which is based on student's cognitive style in order that learning objective can be achieved.

Shuell [11] states that students who have Field Dependent (FD) cognitive style are stronger in receiving social information such as conversation or interpersonal interaction. Speaking of subject, these students are easier to study history and literature. Students with Field Independent (FI) cognitive style are easier to elaborate complex things and solve problems. Therefore, problem solving skill of students with Field independent cognitive style is better than that of students with Field Dependent cognitive style.

Traditional accounting education often produces graduates where only knowledge of the accounting profession but lack of analysis, opinion, communication, and problem solving and other important skills [13].

.This fact can be seen from significant dominance of teacher in transferring knowledge such as giving full guidance in answering accountancy questions. The result was that the quality of the output of our education is lower compared to output of education in other countries. This fact is a signal that there is something wrong with our education system which can be the curriculum, educators, or learning strategy.

Given the fact that there is problem as explained above concerning the importance of problem solving skill in increasing the result of learning Intermediate financial accounting and other essential skills and the role of cognitive style in solving problems concerning financial accountancy, the research entitled "The Influence of Problem Based Learning Model and Cognitive Style on The Result of Learning Intermediate financial accounting 2".

\section{METHOD}

This research was quasi experiment research. Experiment group was taught by using Problem Based Learning and control group was taught by using drill method in small group.

The research plan which was used was: two group : pre test, and post test design. The design is represented as follows:

\section{RESEARCH DESIGN}

$$
\begin{array}{cccc}
\mathrm{E}_{1} & \mathrm{O}_{1} & \mathrm{X}_{1} & \mathrm{O}_{2} \\
\mathrm{E}_{2} & \mathrm{O}_{1} & \mathrm{X}_{2} & \mathrm{O}_{2}
\end{array}
$$


Table o1, Cont.

The test instrument was used to take the data of the result of learning AKM 2. The data was got through pre test and post test which would be analysed item by item. The data was analysed with validity test, reliability test, discriminating power, and level of difficulty of the questions. To test the cognitive style of students, the researcher used GEFT (Group Embedded Figures Test) which was developed by

Notes :

$\mathrm{E}_{1} \quad$ : Experiment Class

$\mathrm{E}_{2}:$ Control Class

$\mathrm{O}_{1}:$ Pre Test

$\mathrm{O}_{2}$ : Post Test

$\mathrm{X}_{1}$ : Model Problem Based Learning Implementation

$\mathrm{X}_{2}$ : Conventional Method (Drill method in small group)

Witkin (1971). The validity of the instrument was established by determining its relationship with the parent test, the Embedded Figures Test (EFT), as well as the Rod and Frame Test (RFT), and the Body Adjustment Test (BAT). The GEFT is a timed test, therefore internal consistency as a measure of reliability was measured by treating each section as split halves $(r=0.82)$ [14 ]

The documentation was used to collect the research data from the students' learning result in previous period. The profile of accountancy education program of FKIP UIR was also collected. The observation was used to observe the process of PBL method in experiment class and conventional learning in control class.

The population of this research was all students who started attending college in education year 2014/2015 who was at $4^{\text {th }}$ semester and had Intermediate financial accounting 2 at the time the research was conducted. The population consisted of 4 classes (from class A to class D). The sample was collected by using purposive sampling technique by considering academic skill and character of the most equivalent student. The homogeneity test was also conducted. The sample was then chosen randomly and it was determined that experiment class was class $4 \mathrm{C}$ and control class was class 4D.

The implementation of PBL in experiment class is presented in Table 01 as follows:

Table 01: The Implementation of PBL in Intermediate Financial Accounting

\begin{tabular}{|l|l|l|l|}
\hline $\begin{array}{l}\text { Stanley \& } \\
\text { Marsden } \\
(2012),[17]\end{array}$ & $\begin{array}{l}\text { Hong } 2004),[7] \\
\text { 2001, }\end{array}$ & Activity & Info \\
\hline
\end{tabular}

\begin{tabular}{|c|c|c|c|}
\hline Facts & & Educators & $\begin{array}{l}\text { Educator } \\
\text { explained key } \\
\text { concepts } \\
\text { concerning topic } \\
\text { that would be } \\
\text { taught. The topic } \\
\text { was about } \\
\text { Stakeholder } \\
\text { Equity which } \\
\text { covered the } \\
\text { characteristic and } \\
\text { classification of } \\
\text { share, } \\
\text { accountancy of } \\
\text { share sum, } \\
\text { publication, } \\
\text { lump tre sum } \\
\text { treasury share } \\
\text { accountancy, and } \\
\text { share splitting- } \\
\text { up. }\end{array}$ \\
\hline $\begin{array}{l}\text { Facts } \\
\text { Ideas } \\
\text { Research }\end{array}$ & $\begin{array}{l}\text { Individual } \\
\text { learning }\end{array}$ & $\begin{array}{l}\text { Self - directed } \\
\text { learning }\end{array}$ & $\begin{array}{l}\text { Each group } \\
\text { should submit } \\
\text { and read the data } \\
\text { concerning topic } \\
\text { which had been } \\
\text { determined by } \\
\text { teacher. Teacher } \\
\text { will provide } \\
\text { access to } \\
\text { learning resource } \\
\text { that can be dug } \\
\text { by students to } \\
\text { collect data } \\
\text { including } \\
\text { financial } \\
\text { accountancy } \\
\text { books } \\
\text { financial and } \\
\text { accountancy } \\
\text { standard } \\
\text { together. }\end{array}$ \\
\hline Research & $\begin{array}{ll}\text { Small panel } \\
\text { discussions }\end{array}$ & $\begin{array}{lr}\begin{array}{l}\text { First } \\
\text { before }\end{array} & \text { part } \\
\text { discussion } & \text { at } \\
\text { class } & \end{array}$ & $\begin{array}{l}\text { Each group } \\
\text { member met up } \\
\text { once a week to } \\
\text { discuss what } \\
\text { they had } \\
\text { collected and } \\
\text { prepare the } \\
\text { answer for topic } \\
\text { discussion. }\end{array}$ \\
\hline
\end{tabular}


Table 01, Cont

\begin{tabular}{|c|c|c|c|}
\hline Research & $\begin{array}{l}\text { Discussion with } \\
\text { teacher }\end{array}$ & $\begin{array}{l}\text { Discussion } \\
\text { with teacher }\end{array}$ & $\begin{array}{l}\text { Teacher should } \\
\text { discuss with the } \\
\text { group that would } \\
\text { perform the } \\
\text { following week } \\
\text { to help } \\
\text { accelerating the } \\
\text { identification to } \\
\text { solve problem. } \\
\text { Teacher could } \\
\text { also help the } \\
\text { group to } \\
\text { organize the } \\
\text { answer in order } \\
\text { that the answer } \\
\text { appropriate for } \\
\text { the content and } \\
\text { the goal of } \\
\text { learning. }\end{array}$ \\
\hline Research & $\begin{array}{l}\text { Students learn } \\
\text { independently in } \\
\text { group discussion } \\
\text { meeting }\end{array}$ & $\begin{array}{l}\text { Learning } \\
\text { second part } \\
\text { before class } \\
\text { discussion }\end{array}$ & $\begin{array}{l}\text { Each group } \\
\text { member should } \\
\text { discuss again } \\
\text { what they had } \\
\text { learn from the } \\
\text { first discussion } \\
\text { with teacher. The } \\
\text { aims of this } \\
\text { discussion were } \\
\text { to give each } \\
\text { member } \\
\text { conviction that } \\
\text { they had } \\
\text { understood the } \\
\text { discussion topic } \\
\text { and to prepare } \\
\text { preparation } \\
\text { (material) for } \\
\text { performing at } \\
\text { class. }\end{array}$ \\
\hline $\begin{array}{l}\text { Decide } \\
\text { Execute }\end{array}$ & Class discussion & Class report & 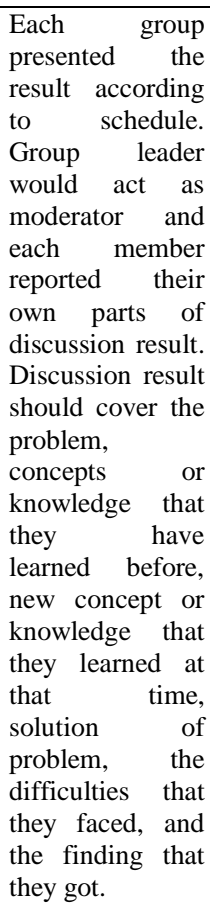 \\
\hline
\end{tabular}

Table 01, Cont

\begin{tabular}{|l|l|l|}
\hline Group inquiry & $\begin{array}{l}\text { During the class } \\
\text { report the group } \\
\text { that had not } \\
\text { performed ask } \\
\text { should } \\
\text { question } \\
\text { according to the } \\
\text { topic and the } \\
\text { group that was } \\
\text { performing } \\
\text { should give the } \\
\text { answer. Teacher } \\
\text { must provide } \\
\text { additional } \\
\text { information if } \\
\text { the answer from } \\
\text { the group that } \\
\text { was performing } \\
\text { was not suitable. }\end{array}$ \\
\hline
\end{tabular}

$[5]$

The techniques that were used in this research are as follows:

1. The analysis of dummy variable regression

Dummy variable is categorical variable that is assumed to have influence towards continuous variable. In this research, the term categorical variable referred to PBL method which was symbolized with (1) and drill method in small group which was symbolized with (0). Meanwhile, cognitive style FI was symbolized with (1) and cognitive style FD was symbolized with (0).

\section{The analysis of independent t test}

This analysis was used to find out the influence of PBL model on the result of learning Intermediate financial accounting 2 through difference test where PBL model was compared to drill method in small group.

The data analysis in this research was conducted with the help of a program named SPSS 17.

\section{FINDINGS AND DISCUSSION}

From the result of data analysis, it was found that the result of pre test of control group and experiment group showed that the mean score of experiment class was 53.75 and the mean score of control class was 48.06. Experiment class had 5.69 more points. The result of post test of control group and experiment group showed that the mean score of experiment class was 40.21 and the mean score of control class was 44.33. Control class had 4.12 more points. The difference was only 4.12 points or less than 5 points and it meant that there was no significant difference on the result of learning Intermediate financial accounting 2 in learning topic of Stakeholder Equity. 
When the conventional learning method (drill) in small group was applied in both classes, the result of pre test showed that the score of experiment class was higher than that of control class where experiment class had 5.69 more points. However, when Problem Based Learning was applied, the result was the contrary. The post test showed that the score of experiment class was lower than that of control class. Therefore, the implementation of Problem Based Learning was less effective compared to the implementation of drill method in small group on the material of Stakeholder Equity. Although in both classes there was decrease of score, the result of gain score showed that compared to control class, experiment class had more students whose score decreased.

In experiment class, there were 15 students $(62.5 \%)$ whose score decreased. There were 3 students (12.5\%) whose score was constant and there were 6 students (25\%) whose score increased. Meanwhile, in control class, there were 9 students $(50 \%)$ whose score decreased. There were 5 students $(27.78 \%)$ whose score was constant and there were 4 students $(22.22 \%)$ whose score increased. Based on the data mentioned above, in post test, the percentage of the number of students whose score decreased in experiment class was bigger than the percentage of the number of students whose score decreased in control class. The difference was $12.5 \%$. Therefore, the level of difficulty of post test questions was higher than the level of difficulty of pre test questions.

Talking about cognitive style, it was found that there were 4 out of 24 students (16.67\%) in experiment class whose cognitive style was FI and the rest (20 students $/ 83.33 \%$ ) were categorized into FD. Meanwhile, in control class, there were only 2 out of 18 students (11.11\%) who were categorized into FI and the rest (16 students/88.89\%) were categorized into FD. In experiment class, compared to FD category, students in FI category had higher mean score of pre test and pro test. The mean score of pre test of FI students were 60 and the mean score of post test of FI students was 41.25. Meanwhile, the mean score of pre test of FD students were 52.5 and the mean score of post test of FD students was 40.

On the contrary, in control class, the mean score of pre test and post test of FD students was higher. The mean score of pre test of FD students were 50 and the mean score of post test of FD students was 46.75. Meanwhile, the mean score of pre test of FI students were 32.5 and the mean score of post test of FI students was 25. Therefore, this data strengthened the result of data analysis which stated that cognitive style did not have significant influence on the result of learning Intermediate financial accounting 2.
Table 02 The Result of Dummy Regression

\begin{tabular}{|c|c|c|c|c|c|c|}
\hline \multicolumn{7}{|c|}{ Coefficients $^{a}$} \\
\hline & & \multicolumn{2}{|c|}{$\begin{array}{l}\text { Unstandardized } \\
\text { Coefficients }\end{array}$} & \multirow{2}{*}{\begin{tabular}{|l|}
$\begin{array}{l}\text { Standardi } \\
\text { zed } \\
\text { Coefficie } \\
\text { nts }\end{array}$ \\
Beta \\
\end{tabular}} & \multirow[b]{2}{*}{$\mathrm{t}$} & \multirow[b]{2}{*}{ Sig. } \\
\hline \multicolumn{2}{|c|}{ Model } & B & Std. Error & & & \\
\hline \multirow[t]{3}{*}{1} & (Constant) & $\begin{array}{l}38.47 \\
1\end{array}$ & 5.513 & & 6.978 & .000 \\
\hline & $\begin{array}{l}\text { Cognitive } \\
\text { style }\end{array}$ & .347 & .822 & .068 & .423 & .675 \\
\hline & PBL Model & 3.816 & 5.661 & .108 & .674 & .504 \\
\hline
\end{tabular}

Table 02 showed that the Sig. value of cognitive style was $0.675>0.05(\alpha)$ and therefore H0 was accepted and $\mathrm{H} 1$ was rejected. Therefore, it can be concluded that there was no significant influence of cognitive style on the result of learning Intermediate financial accounting 2. Then, for PBL model, it was found that the Sig. value was 0.504 > $0.05(\alpha)$ and therefore $\mathrm{H} 0$ was accepted and $\mathrm{H} 1$ was rejected. Therefore, it can be concluded that there was no significant influence of PBL model on the result of learning Intermediate financial accounting 2.

Table 03 The Test Results of Simultaneous

\begin{tabular}{|c|c|c|c|c|c|}
\hline ANOVA $^{\text {a }}$ & & & & & \\
\hline Model & $\begin{array}{l}\text { Sum of } \\
\text { Squares }\end{array}$ & Df & Mean Square & $\mathrm{F}$ & Sig. \\
\hline Regression & 232.915 & 2 & 116.458 & .359 & $.700^{\mathrm{b}}$ \\
\hline Residual & $\begin{array}{l}12642.06 \\
1\end{array}$ & 39 & 324.155 & & \\
\hline Total & $\begin{array}{l}12874.97 \\
6\end{array}$ & 41 & & & \\
\hline $\begin{array}{l}\text { a. Depender } \\
\text { accounting } 2\end{array}$ & Variable: : & resu & learning inte & ediate & financia \\
\hline
\end{tabular}

The result of simultaneous test of the influence of cognitive style and PBL model on the result of learning Intermediate financial accounting 2 can be seen in the following table 03 .

Table 03 showed that the Sig. value was $0.700>0.05$ $(\alpha)$ and therefore it can be concluded that simultaneously 
there was no significant influence of cognitive style and PBL model on the result of learning Intermediate financial accounting 2 .

The difference between conventional model (drill method in small group) and PBL model can be analysed from the result of independent $t$ test. The result of $t$ test with normality and homogeneity which were used as requirements can be seen in the following table 04 .

Table 04 normality test of post test

\begin{tabular}{llll|l} 
& & UAS_4C & UAS_4D \\
\hline $\mathrm{N}$ & & 24 & 18 \\
\hline Normal Parameters & & & \\
& Mean & 40.2083 & 44.3333 \\
\cline { 2 - 4 } & Std. Deviation & 19.30753 & 15.57902 \\
\hline Most Extreme Differences & Absolute & .160 & .128 \\
\cline { 2 - 4 } & Positive & .160 & .099 \\
\cline { 2 - 4 } & Negative & -.152 & -.128 \\
\hline Test Statistic & & .160 & .128 \\
\hline Asymp. Sig. (2-tailed) & & $.115^{\mathrm{c}}$ & $.200^{\mathrm{c}, \mathrm{d}}$ \\
\hline
\end{tabular}

Based on the result of test with KolmogorovSmirnov as seen in table 04, it was found that the Sig. value of experiment class (4C) was $0.115>0.05$ and the Sig. value of control class (4D) was $0.200>0.05$ and therefore the data of post test of both experiment class and control class had normal distribution.

\section{Table 05 Test of Homogeneity Post Test}

Test of Homogeneity of Variance

\begin{tabular}{lll|l|l|l} 
& \multicolumn{2}{c}{$\begin{array}{c}\text { Levene } \\
\text { Statistic }\end{array}$} & df1 & df2 & Sig. \\
\hline UAS & Based on Mean & 2.774 & 1 & 40 & .104 \\
\cline { 2 - 6 } & $\begin{array}{l}\text { Based on Median } \\
\text { Based on Median }\end{array}$ & 2.887 & 1 & 40 & .097 \\
$\begin{array}{l}\text { Band with } \\
\text { adjusted df on }\end{array}$ & 1 & 39.779 & .097 \\
\hline $\begin{array}{l}\text { Based } \\
\text { trimmed mean }\end{array}$ & & 1 & 40 & .105 \\
\hline
\end{tabular}

Table 05 showed that data Based on Mean was 0.105 which was bigger than alpha $(\alpha)$ which was $5 \%$. Therefore, Sig, value was $0.206>0.05$ and it can be concluded that the data of post test of control class and experiment class was homogenous.
Table 06 Test of $\mathrm{t}$ test independent

\begin{tabular}{|c|c|c|c|c|c|c|c|c|}
\hline & \multicolumn{7}{|c|}{ t-test for Equality of Means } \\
\hline & & \multirow[b]{2}{*}{$\mathrm{t}$} & \multirow[b]{2}{*}{ df } & \multirow{2}{*}{$\begin{array}{l}\text { Sig } \\
\text { (2- } \\
\text { tail } \\
\text { ed) }\end{array}$} & \multirow{2}{*}{$\begin{array}{l}\text { Mean } \\
\text { Differ } \\
\text { ence }\end{array}$} & \multirow{2}{*}{$\begin{array}{l}\text { Std. } \\
\text { Error } \\
\text { Differ } \\
\text { ence }\end{array}$} & \multicolumn{2}{|c|}{$\begin{array}{l}95 \% \\
\text { Confidence } \\
\text { Interval of } \\
\text { the } \\
\text { Difference }\end{array}$} \\
\hline & & & & & & & $\begin{array}{l}\text { Low } \\
\text { er }\end{array}$ & $\begin{array}{l}\text { Upp } \\
\text { er }\end{array}$ \\
\hline $\begin{array}{l}\text { result } \\
\text { of } \\
\text { learnin } \\
\text { g } \\
\text { interme } \\
\text { diate }\end{array}$ & $\begin{array}{l}\text { Equa } \\
1 \\
\text { varia } \\
\text { nces } \\
\text { assu } \\
\text { med }\end{array}$ & $\begin{array}{l}- \\
.7 \\
4 \\
2\end{array}$ & 40 & $\begin{array}{l}.46 \\
2\end{array}$ & $\begin{array}{l}- \\
4.125 \\
00\end{array}$ & $\begin{array}{l}5.555 \\
89\end{array}$ & $\begin{array}{l}- \\
15.35 \\
388\end{array}$ & $\begin{array}{l}7.10 \\
388\end{array}$ \\
\hline $\begin{array}{l}\text { al } \\
\text { account } \\
\text { ing } 2\end{array}$ & $\begin{array}{l}\text { Equa } \\
1 \\
\text { varia } \\
\text { nces } \\
\text { not } \\
\text { assu } \\
\text { med }\end{array}$ & $\begin{array}{l}- \\
.7 \\
6 \\
6\end{array}$ & $\begin{array}{l}39 . \\
744\end{array}$ & $\begin{array}{l}.44 \\
8\end{array}$ & $\begin{array}{l}- \\
4.125 \\
00\end{array}$ & $\begin{array}{l}5.386 \\
67\end{array}$ & $\begin{array}{l}- \\
15.01 \\
405\end{array}$ & $\begin{array}{l}6.76 \\
405\end{array}$ \\
\hline
\end{tabular}

Table 06 above showed that Sig. value (2-tailed) > alpha where $0.448>0.05$. It meant that Ho was accepted and $\mathrm{Ha}$ was rejected. Therefore, it can be concluded that there was no difference between Problem Based Learning and Drill method in small group in increasing the result of learning Intermediate financial accounting 2. In other words, PBL model did not have significant influence on the result of learning Intermediate financial accounting 2

The result of data analysis showed that PBL model did not have significant influence on increasing the result of learning Intermediate financial accounting 2. Given statements [15]; [16]; [17]; [18], students should have and apply self management, spirit to look for knowledge, and study through group collaboration. With group learning, students are able to contemplate problems from different perspective. By sharing knowledge and opinion, students can create a meaningful knowledge system together.

Based on the observation during PBL implementation, it was found that students lacked curiosity. This phenomenon could be seen from the fact that there were only few students who discussed actively with the lecturer before presenting the result of discussion. It was also found that group discussion process was less maximal since the material concerning Stakeholder Equity was the new material for students. Some group members had little knowledge about the material and therefore many students 
still got confused. Therefore, the discussion did not run well. In addition, students also lacked creativity and spirit to figure out. This fact can be seen from the lack of initiative to get material from another resource.

The weakness that was found was that the presented case was still less perfect. There was still difficulty in designing a case for material concerning stake which was based on students' perspective and what students had known. This difficulty was due to students' knowledge concerning stake which was still very limited. In addition, PBL is a learning model where teacher should design learning curriculum which is based on students' perspective and what students know and use. Students are also expected to organize various resource in their daily life through guided participation. In the end, students can develop skill to solve complex problem that they find in their daily life.

The main characteristic of PBL is that problem is the starting point of learning [13]. Duch [19] states that the learning core and learning objective are connected to problem and in the end this combination can challenge students to develop higher level of thinking such as analysis, synthesis, and evaluation.

Due to the weakness explained above, it can be concluded that there was no significant difference between drill technique in small group and PBL. In other words, this research did not confirm research conducted by Hsu C, Yen S, Lai W [5] in the year 2013 entitled The Effectiveness of PBL in Accountancy Lecture Subject where the result showed that PBL was more effective in increasing the result of learning accountancy compared to traditional method.

Meanwhile, the basic of the reason why cognitive style also did not have influence on the result of learning Financial Accountancy can be explained by connecting the result of this research with the result of research which was conducted by Thomas J Stanley. Thomas J Stanley [20] states that the first 10 out of 100 factors which influence somebody's success are (1) honesty, (2) discipline, (3) easiness to socialize, (4) support from partner, (5) working harder than somebody else, (6) loving what you do, (7) strong and good leadership, (8) spirit and competitive personality, (9) good life management, and (10) the ability to sell ideas and product.

The result of the research showed that the fact that both student with FD cognitive style and student with FI cognitive style got less satisfying result was due to the students who lacked willingness to work harder, competitive spirit, and competitive personality. In other words, when a student has FI cognitive with high score but he/she has no spirit and strong willingness to learn, it can be predicted that he/she cannot achieve satisfying result.
Johnstone \& Biggs (1998) suggests four suggestions for accounting educators in the application of PBL, among others: (1) PBLs are implemented only after knowledge of basic accounting is obtained; (2) problem solving strategies should be explicitly taught; (3) Stimulating an Innovative approach to teach problem solving skills (which focus on small groups and based on student center) (4) for those who apply the PBL already mastered the materials and learning techniques that will be delivered [21].

Therefore based on observations during the research, students feel strange and confused how the steps to start in analyzing a problem, because they are accustomed to solve the questions of accounting with the guidance of lecturers in full, even with the cooperative learning method. Therefore, when the PBL is applied, the result is not maximal because they remain dependent on the lecturer. Therefore, based on Johnston \& Biggs (1998) they need to be taught first problem solving strategies before the PBL is applied. Because of the essence of the PBL model in accounting courses, where with this model can develop problem solving skills that must be owned by accounting students [8] then the suggestions for the next researcher is before applying this model, it must be ascertained that the students already know the strategy in problem solving.

\section{CONCLUSIONS}

Based on the result of the research and analysis explained above, it can be concluded that (1) There was no significant influence of PBL model on the result of learning Intermediate financial accounting 2; (2), There was no significant influence of PBL model on the result of learning Intermediate financial accounting 2. Given the fact that this research has limitation concerning case design which less appropriate for the characteristic of PBL, for the next research, it is advised to design case which is suitable for the knowledge which has been known by students in order that discussion can run well. Since the choosing of material must be adjusted to suit characteristic of PBL, the material which suits PBL is advanced material where students have had knowledge and not basic material. For sample selecting, it is advised to choose sample who have spirit to find information since PBL model emphasizes independent learning. Then the teacher should be able to arouse the spirit of finding out, considering the PBL model is more emphasis on independent learning. And before implementing learning PBL, students should be equipped first a strategy in solving the problem. 


\section{REFERENCES}

[1] Umar, rahmat talatu. 2014. Relationship between Influence of Cognitive Styles and Study Strategies on Academic Performance of Business Education Students in Financial Accounting in Federal Universities in Nigeria. International Conference on Business, Sociology and Applied Sciences (ICBSAS'14) March 26-27, 2014 Kuala Lumpur (Malaysia)

[2] Drennan, L.G. And Rohde, F.H. (2010). Determinants of Performance in Advanced Undergraduate Management Accounting: An Empirical Investegation Journal of Accounting and Finance, 42 (1), 27-40

[3] Lisa Gueldensoph Snyder dan Mark J. Synder, 2008. Teaching critical thingking and problem solving skills. Volume L, No. 2, Spring/summer, 2008.

[4] Huang, S.W. 2001. Ability to rely on the professional judgment of accounting education, Accounting Research Monthly, 307 : 29

[5] Hsu, C. \& Yen, S \& Lai, W. 2013. Effectiveness of Problem Based Learning in the Accounting Course.

[6] Tempelaar, D. T. (2006). The role of metacognition in business education. Industry and Higher Education, 20 (5), 291-297.

[7] Bertlett, J. E. (2002). Analysis of motivational orientation and learning strategies af high school business student, business Education Forum, 56(4), 18-23.

[8] Jones, S.H., \& Wright, M. 2011. Effect Of Cognitive Style On Performance In Introductory Financial Accounting And The Decision To Major I Accounting. Global Perspectives On Accounting Education, (Online), Volume 8, 2011, 7-26, http://web.bryant.edu/ gpae/Vo18/Cognitive\%20Style\%on\%20Per formance.pdf, diakses 10 November 2012.

[9] Carrington, L. G. 2012. Ready For Intermediate Accounting? Factors Affecting Student Preparation, makalah disajikan dalam konferensi Akademik Internasional. Orlando, Florida, USA

[10] Jones, S.H., \& Wright, M. 2012. Does Cognitive Style Affect Performance On Accounting Examination Questions?. Global Perspectives On Accounting Education, (Online), Volume 9, 2012, $31-52$,

http://webbryant.edu/ gpae/Vo19/Cognitive\%20Style\%20Affect\% 20Performance\%20on\%20Exam\%20Questions.pdf, diakses 10 November 2012

[11] Philliphs, F. 1998. Accounting Students' Beliefs About Knowledge: Associating performance with Underlying Belief Dimensions. Issues in Accounting Education (Vol. 13, No. 1) 113126.

[12] Tinajero , C., \& Paramo, M. F. (1997). Field dependenceindependence and academic achievement: A reexamination of theur relationship. British Journal of Educational Psychology, 67, 199-212

[13] Lave, J. \& Wenger, E. 1991. Situated learning: legitimate peripheral participation. Cambridge, UK: Cambridg University Press.

[14] Garton, B.L, Dyer J.E, King, B.E . 2000. The Use Of Learning Styles And Admission Criteria In Predicting Academic Performance And Retention Of College Freshmen. Journal of Agricultural Education, Volume 41 Number 22. Pp 46-53

[15] Wang, G. S. 2012. PBL and critical thinking. In C. H. Ynag (Eds), $P B L$ teaching pretice - in national yilan university experience and reflection: 44-53. Yilan Caunty: National Yilan University.

[16] Hmelo, C. E., D. L. Holton \& J.L. Kolodner. 2000. Designing to learning about complex systems, Journal of the Learning Sciences, 9 : 247-298.

[17] Schmidt, H. G. \& J. H. C. Moust. 1995. What Makes a Tutor Effective? A Structural-Equations Modeling Apporoach to
Learning in Problem-Based Curricula, Academic Medicine, 70 (8) : 708-714.

[18] Trop, L. \& S. Sage 2002. Problem as Possibilities: problem-based learning for $K-16$ education (2nd ed.). alexandria, VA: Association for Supervision and Curriculum Development.

[19] Duch, B. J. 2001. Models for problem-based instruction in undergraduate courses. In B. J. Duch, S. E. Groh, \& D. E. Alen (Eds.), The power of problem-based learning-A pratical "How to" for teaching undergraduate courses in any disclipline. Sterling: stylus publishing, LLC.

[20] Chandra dan Rahman. 2016. Why School Is Not Enough. Jakarta: Literatur Negeri

[21] Johnstone, K. \& Biggs, S. 1998. Problem-based learning: Introduction, analysis, and accounting curricula implications. Journal of Accounting Education, 16 (3/4) :407-427.

[22] Dimyati Mahmud. 2009. Psikologi Pendidikan Suatu Pendidikan Terpadu. Yogyakarta: BPFE.

[23] Hong, R. J. 2001. PBL Teaching Strategies. Quartely Journal of Technological and Vocational Education, $61: 10-12$

[24] Lave, J. \& Wenger, E. 1991. Situated learning: legitimate peripheral participation. Cambridge, UK: Cambridg University Press.

[25] Shakirova, D. M. (2007). Technology for the shaping of college students' and upper-grade students' critical thinking. Russian Education \& Society, 49 (9), 42-52. Dalam Snyder.

[26] Stanley Trevor \& S. Marsden 2012. Problem-based learning Does accounting education need it? Journal of Accounting Education, 30:267-289.

[27] Witkin, H. A. 1971. The Role of Cognitive Style in Academic Performance and in Teacher-Student Relations. Education Resources Information Center: Paper presented at a Symposium sponsored by the Graduare Record Examination Board, Montreal, Canada, November 8-10, 1972 